\title{
Community engagement Finding history where it lives
}

A n African American community activist and business owner was looking for an institution that would collect documents and assist in conducting oral histories from communities across Southern Illinois to "tell the story of the region's African-American Heritage." ${ }^{1}$ Southern Illinois University Carbondale's Special Collections Research Center (SCRC) answered the call. SCRC has been committed to collecting and providing access to materials that represent diversity of race, economic status, gender and sexuality, religion, and politics in southern Illinois.

SCRC is part of an academic library on a medium-sized university campus in a rural part of Illinois. It has always been a part of the mission of Special Collections to document the history of the local community since its establishment in 1956. However, a more directed effort to be more proactive in community engagement beyond town and gown, as well as to diversify the local collection, began in the 2000 s.

\section{Planning and preparation}

The community activist, together with two faculty from SCRC and a member of the Southern Illinois University-Carbondale (SIUC) History Department/Africana Studies faculty, worked together to plan a project to document the African American experience in southern Illinois. ${ }^{2}$ Reclaiming the African American Heritage of Southern Illinois was to focus initially on assisting community members to preserve and share their personal archives and stories. The project would also provide guidance on how they could donate their materials to an archive if they wished, so that their stories could be preserved and made available to current and future students and community members.

In late fall 2017, the project team held an open discussion on the SIUC campus with local church leaders and interested community members. The inaugural meeting was to be inclusive and to help make connections and foster future collaborative opportunities. We sent letters from the committee to local churches, temples, mosques and organizations, following up with personal phone calls, as well as placed notices on social media and in church bulletins.

The overall aim of this project was to help community members tell their own history in ways that were authentic and meaningful to them. At this meeting, the community activist stressed the important role of Black community members in preserving their history for current and future generations. The SIUC history faculty member demonstrated the importance of keeping stories alive and the impact these have on the historical record. She talked about her own research using records from Black church communities in Pittsburgh. The archivists reviewed what an archive could do to assist in this process, and specifically how SCRC could be a home for such collections.

The result of this conversation was to identify potential churches, organizations, and individuals who might have information that should be

Pam Hackbart-Dean is the head of Special Collections and University Archives, email: phdean@uic.edu at the University of Illinois-Chicago, and Walter Ray is the political papers archivist, email: wray@lib.siu.edu, at Southern Illinois University-Carbondale

(C) 2021 Pam Hackbart-Dean and Walter Ray 
preserved and may be interested in working toward this end. The group identified local nonprofit organizations, businesses, churches, political groups, individuals, and families. The goal was to document the character of the community, the people who live and work there, and services they provide. To build trust and accountability, the community activist and three faculty members worked with community members to set up events where individuals, families, or organizations could get advice on how to care for their historical records, start their own family or community archives, or how to donate their materials to an archive.

\section{Community events}

Community events would be held at churches, community centers, and even family reunions. A team member or members were to be available to churches, and community centers in the area. At most of the gatherings the community members wished to donate copies of their collections to the university but keep the originals. The project archivist has conducted a number of oral history interviews to add to the collection.

\section{Accountability}

"If you're narrowly studying academic users, there's a sense [of] a cool distance between researchers and their materials," says Michelle Caswell of UCLA. "But if you're interviewing activists, artists, or community members who see themselves sometimes quite literally in the collections and materials, there might be an emotional response to seeing themselves represented. Community archives foster something we're calling representational belonging. There's an affect; an emotional dimen-

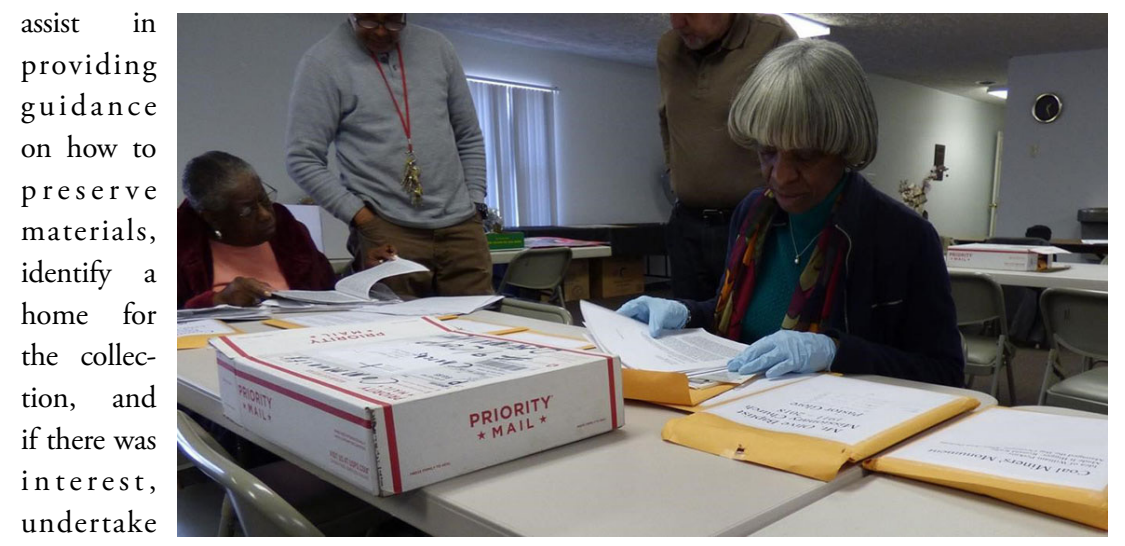

oral histo- Project Team member, Pamela Smoot, SIUC Department of History, reviews ries. It is papers at community event held in Colp, Illinois, 2018. Image courtesy important of Mary Halstead.

to work

flexibly and collaboratively with these organizations and individuals in order to broaden access and to preserve their stories.

The first official community event was held on a Saturday afternoon in early 2018 at the Mt. Olive Baptist Church in Colp, Illinois. Attendees included church and community members, the local historian of Colp, and the local press. During this event, the public donated rescued church records, research materials about the history of Colp, and funeral programs to the university. Questions were also answered on how to collect and preserve their own family papers for future generations.

More events have been held at family reunions, sion of seeing yourself represented in archives when . . . you felt excluded before. " 4

I $t$ is important for those donating materials to SCRC that their papers be accessible to students and community members. This was also a priority for the archivists, who work to get the collections processed and to provide online access to them. Beyond making collections accessible, it is necessary to keep engaging the community in this ongoing initiative. A quarterly e-newsletter is sent to those who attended the initial community meeting or subsequent gatherings, donors, and interested community members, to update the group about newly donated collections, recently processed collections, identification of related archives in the area, and any events that have been held.

In addition, a Facebook page has been developed to publicize the project and provide a forum 
to discuss the rich history of African Americans in southern Illinois. ${ }^{5}$ All collections that have been donated to the university included transfer of copyright. These donations are available for research and information about them can be easily accessed online.

\section{Lessons learned}

Getting word out about the project was essential for the project to move forward. SCRC created a brochure to explain the project's goals and provide contact information for those interested in it. Project team members have handed out hundreds of these brochures. They can be found in church halls and on bulletin boards all over Southern Illinois. The e-newsletter and Facebook page have helped keep the project in the minds of the target audience.

Leveraging local media has added another dimension to the project's outreach. Team members have developed relationships with local reporters, who have covered project events. This has enabled the project to reach a broader audi-

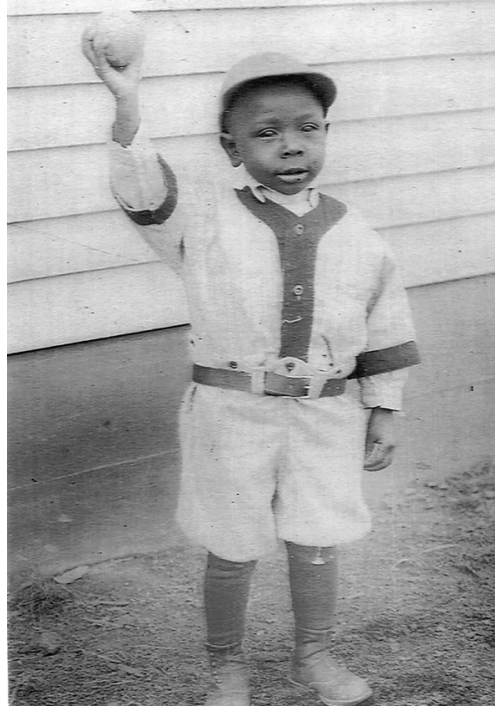

Arville "Baby" Riggins Jr., son of baseball shortstop in the Negro Leagues Arville "Bill" Riggins of Colp, is pictured in his baseball uniform circa 1925. From Ronald Kirby collection. ence. The Facebook page also helps reach a broad audience.

Building relationships between archivists and the community has been of singular importance to the success of the project. This has meant being present in the community and going to community events, church concerts and anniversaries, MLK Day breakfasts and luncheons, Memorial Day commemorations, and meetings of local organizations like the NAACP and Women for Change. Patience and perseverance are needed to develop relationships. It takes time to build trust. Oral history interviews are a valuable way to complement the material record and have also proven to be an effective tool for establishing and fostering relationships.

There is a ready audience out there, those who have an interest in preserving community history and have been looking for ways to do this, like the community member who reached out to begin the project. Many have already been gathering materials and are anxious to have them preserved. Some have self-published collections of reproduced documents and memoirs. Such individuals are also valuable advocates for the project. Working through churches has been effective because pastors know their congregations and whom to approach.

Success breeds success. As community members have seen collections preserved and made accessible, many have shown greater interest in the project and a willingness to donate their materials to a community archives or the university itself. News that the project had received the 2019 SIU Diversity Excellence award prompted one organization, with whom archivists had been talking for several years, to donate its records to SCRC.

\section{Future plans}

Thus far, the project has focused its efforts on three Southern Illinois communities (Colp, Creal Springs, and Carbondale), while accepting other donations from the region as they have been offered. The goal will be to expand the project to other communities without losing focus on the intent of the original project or overtaxing limited archival resources. Thinking beyond seeking donations from community members, SUIC's Special Collections will provide archival precepts and impartial legacy management advisement to our community, including helping communities archive their own collections, donor education, and post-custodial agreements.

The project team plans to expand its capabilities by working more closely with local museums, historical societies, and community archives. What is important is not where the records are preserved but that they are preserved and accessible. The project can serve as a research hub documenting 
where materials can be found and can provide guidance on how communities can tell their story and how to preserve them.

When it becomes possible, the team plans to organize exhibitions and events that highlight materials already collected by the project. This will give community members the opportunity to see that their efforts and contributions are bearing fruit and encourage others to get involved.

\section{Notes}

1. Marilyn Halstead, "Finding History Where It Lives: Group Works to Document AfricanAmerican History in Southern Illinois," Southern Illinoisan, February 22, 2018.

2. Becky Malkovich, "Finding freedom in small African American communities," Southern Illinoisan, October 18, 2011. Southern Illinois was home to several early free black settlements. Several of these communities were settled by African Americans freed before the Civil War. Other communities were established around the turn of the 20th century when coal mining companies recruited African Americans, usually from Tennessee and Kentucky, to work in the mines.

3. These records were rescued from of the Caledonia Freewill Baptist Church, an African American church located in Olmstead, Illinois, that was being torn down the next week.

4. Michelle Caswell, "Community Archives," Knowledge that Matters blog, November 5, 2018, https://sudikoff.gseis.ucla.edu/communityarchives/ (accessed 10/19/2020).

5. The inspiration for the Facebook page came from the success of the Georgia LGBTQ Archives Project as discussed in Morna Gerrard's article, "No Fame Required': Collaboration, Community, and the Georgia LGBTQ Archives Project," in Kate Theimer, ed., Appraisal and Acquisitions: Innovation Practices for Archives and Special Collections (Landham: Rowman and Littlefield, 2015): $1-15 \geq 2$

("Streaming access in a fractured world," continued from page 376)

their use. We hope to continue this trend after we return to in-person instruction.

\section{Areas for improvement}

Our current process developed over the course of the fall semester as we responded to faculty and student needs. This required extended and extensive communication between the Office of Technology Services, CELTT, and (of course) multiple library departments. With so many variables in the process, miscommunication was common, work was sometimes duplicated, and requests took more time and effort. We intend to collaborate with colleagues to simplify our workflow and to learn from the mistakes made during COVID-19 adaptation. This process of self-reflection and peer discussion should help improve access now and after COVID-19.

\section{Summary}

LibGuides provided a solution to an issue that complicated student learning and provided a better user experience, which improved student engagement and (hopefully) increased long-term student use of library resources. Working with streaming media during COVID-19 has caused us to reflect on how we can streamline processes and improve outcomes when we return to in-person instruction. Along the way, we have found ways that we can work across departments and colleges to provide access to streaming media and to improve the process for all involved.

\section{Notes}

1. "Fair Use and Copyright for Online Education: Examples: Video," University Libraries, University of Rhode Island, updated September 15, 2020, https://uri.libguides.com/fairuse/examples /video.

2. Jeff Johnson, Designing with the Mind in Mind, 2nd ed. (Waltham, MA, Morgan Kaufman, 2014).

3. Debbie Li, "Streaming Video Resources at the RLB Library," RLB Library, University of Baltimore, updated December 2, 2020, https://ubalt.libguides.com/c.php?g=1093715\#s -lg-box-25294647.

4. Sarah Gilchrist, "HIST 204: African American History to 1865," RLB Library, University of Baltimore, updated December 3, 2020, https:// ubalt.libguides.com/history/hist204. n 